\title{
The Continuing Debate over Academic Branch Libraries
}

\section{Leon Shkolnik}

To centralize or decentralize: that is the question. Librarians have debated the organization of the academic library for the last century. This article analyzes both sides of the debate, placing each in its proper historical perspective. The author presents prospects for the future organization of the library in light of current trends and technological developments. persuasive arguments. The debate concerns one vigorously contested issue: Should the academic library be centralized in one main building or should it be decentralized into several branches based on differing divisional schemes? For the purposes of this paper, the terms departmental and branch library will be used interchangeably. Both sides of the debate will be examined and some views for future developments presented.

The literature distinguishes three types of branch libraries. First, there is the professional library, such as a law or medicine library. In general, few librarians believe that these distinctively specialized libraries should be incorporated into the main library. The second type of library is the undergraduate library, which is separated from the main branch because of the nature of its clientele. Many professionals believe that the undergraduate library should provide a multitude of services that cannot be offered in a modern research library. Finally, there is the departmental library, a

library established to serve a university academic department. This type of library fuels continuous debate and will be the major focus of this paper.

The concept of the distinctive departmental library separate from the main library building grew out of the seminar movement in late nineteenth-century Germany. German faculty members found it preferable to use their own collections of books in their graduate seminars rather than rely on the resources of the existing, but antiquated, library system. Their books were usually more up to date and were kept in the faculty members' offices for easier access. Charles Kendall Adams first introduced this European concept in the United States when he used it in his English constitutional history class at the University of Michigan. ${ }^{1}$ From this beginning, the practice of using a private collection to teach a seminar led to the development of the departmental library.

The reasons for the early acceptance of departmental libraries are many and varied. Louis T. Ibbotson observed that the departmental library started as a protest. In the late nineteenth century, American education was at a critical juncture. Education had greatly expanded, and

Leon Shkolnik is Head of Reference, D'Youville College Library, D'Youville College, Buffalo, New York 14201. 
that expansion created a severe need for books - a need the university library could not meet. Ibbotson believed that the library was "asleep" and that "on the whole it had never been awake and was very slow in waking." ${ }^{2}$ In Ibbotson's opinion, the late nineteenth century was an American education renaissance to which the university library was indifferent. It awoke only after the departmental library had usurped its place on campus. ${ }^{3}$ In 1929, Mary C. Venn observed that university libraries, basically collections of classical texts and commentaries, were out of step with the educational process. Endowments, permanent book funding, and comprehensive policies of book selection were all lacking.

Departmental libraries were the natural outgrowth of the days when libraries were mere prisons for books. ${ }^{4}$ Librarians were afraid to let the books out of their sight, an attitude that destroyed any idea of service to the community. As Venn wrote, "A librarian protected her books as a lioness her cubs." ${ }^{15}$ While local conditions determined the extent of decentralization, clearly the growth of education in the late nineteenth century, the concepts brought from Germany, and the woeful state of university libraries combined to create the departmental library system. ${ }^{6}$

By the end of the nineteenth century, the issues concerning decentralization of the university library had developed into their modern form. In 1895, Zella Allen Dixson, an associate librarian at the University of Chicago, stipulated certain advantages and disadvantages of decentralization. With few exceptions, these arguments still dominate the literature. Dixson stated that the major advantage of decentralization was that it would allow the student of a certain discipline to become familiar with the bibliography of that discipline-"like a workman with his tools." ${ }^{7}$ This familiarity would encourage individuals to pursue original research and study because access to resources was so convenient. The disadvantages of such a system were two. First, departmental libraries could be physically distant from each other, which could cause innumerable administrative problems. Second, decentralization would tend to result in a narrowness of study, thus defeating the purpose of a total "liberal" education. ${ }^{8}$ Clearly, the notion of interdisciplinary study is hardly new; it was recognized and debated a century ago.

In 1898, George H. Baker, a librarian at Columbia University, observed the many difficulties inherent in a decentralized library system. The cost of materials would grow immensely. Duplication of works would be necessary to meet the needs of various departments. The administrative costs would overburden even the most affluent of universities. Additional staff would be needed to operate the many branches efficiently. Security would be a problem; the danger of book losses would grow as the number of libraries grew. Finally, Baker noted the inconvenience of access to a collection for a person not from that department. ${ }^{9}$

\section{The debate over branch libraries has centered on one conflict: Librarians wish to centralize libraries to increase administrative control, while the faculty opposes centralization.}

William Warner Bishop of the Polytechnic Institute of Brooklyn observed that a major issue of decentralization would be the sense of possession, ownership, and control of each departmental library. ${ }^{10}$ Each department would consider its library its personal domain, independent from the whole. The faculty would not be willing to give up this source of prestige and control for the benefit of the entire university system. Bishop contended that any benefits of a decentralized system would be attained at the expense of economical and efficient supervision and direction. ${ }^{11}$ How, for example, would a departmental library cope with the complexities of cataloging, classifying, inventorying, repair ing, and binding materials? ${ }^{12}$ These turnof-the-century librarians clearly delineated the issues in the centralized versus decentralized academic library debate. 
As the twentieth century progressed, however, both sides found additional evidence to strengthen their positions.

In the twentieth century, the debate over branch libraries has centered on one conflict: librarians wish to centralize libraries to increase administrative control, while the faculty opposes centralization because it means a decrease in their authority, control, and prestige. The library literature is replete with articles presenting the pros and cons of each system. While these arguments for and against departmental libraries seem diametrically opposed, they both stress that local conditions are always the major determinant for the organization of the entire library. A small college has less need for branches than does a large university. The debate, therefore, really pertains only to the largest and most research-oriented academic communities.

\section{DECENTRALIZATION}

The major point favoring a decentralized system concerns access to materials. Proponents of decentralization argue that literature on specific disciplines should be located near places of instruction and research. In other words, immediate accessibility is the most important feature in the use of books. ${ }^{13} \mathrm{~A}$ faculty member at a university will walk no further to a library from his office than he will to his car. ${ }^{14}$ Libraries should be organized to offer information in a way most useful to patrons. In 1983, Hugh C. Atkinson wrote, "We are not really in the business of running libraries, we are in the business of providing library service."15 Atkinson also stated that staff members in smaller libraries are happier and that any group consisting of more than ten to thirteen members will become bureaucratic and lose sight of the goal of service. ${ }^{16}$

The decentralization argument is based on the theory that use of a collection is directly related to access to it. ${ }^{17}$ That is, ease of use is as important as access. Proponents of decentralization argue that because the sheer bulk of the collection is distributed throughout several branch libraries, a closer librarian- user relationship can develop. The librarian would become a subject matter specialist who could deal more efficiently with the unique problems of a particular discipline. Discussing the huge collection at Harvard University, Douglas Bryant argued that even utilizing a branch of one million was more convenient than using a general collection of seven million. ${ }^{18}$

\section{The decentralization argument is based on the theory that use of a collection is directly related to access to it.}

Advocates of decentralization also believe that branch libraries result in a closer librarian-faculty relationship, which leads to greater faculty support of the library. When faculty members believe they have a stake in the growth and development of the collection, they are more likely to provide support than if they view the library as one great and distant monolith. This support helps develop greater endowments. Cooperation between librarians and faculty benefits the librarians' mission to disseminate information to users. Teaching faculty believe that in a departmental arrangement they have greater input into book selection and acquisition, which, in turn, provides a more effective system of collection development. ${ }^{19}$

Other advantages of decentralization, as discussed by Snunith Shoham in 1982, include a flexible loan policy designed to meet the needs of the department, more personal attention from the staff, more direct service to a particular group, more collection responsiveness to users, and speedier searches. ${ }^{20}$ In general, a decentralized structure, ideally, would respond more directly to the needs of the users. Because this is the goal of the library in general, decentralization, supporters argue, necessarily would be the preferred arrangement.

Generally, older and larger libraries are more apt to be decentralized..$^{21}$ Robert $\mathrm{R}$. Walsh believes there are two main causes for this fact: The sheer bulk of the 
collection necessitates some kind of decentralized plan, and small offices or laboratories adding to their collections often create small libraries. If the main library has room to expand physically, branches can be avoided, but this is often not possible. When funds are available, branch libraries seem to be the logical solution for the problem of space and the needs of a growing library clientele. ${ }^{22}$

Many other points of debate exist. Proponents of decentralization hold that separation of the library from the laboratories and the classrooms is not cost effective. It is not efficient to have highly paid faculty members walking between their classrooms or laboratories and a distant central library when all their materials could be close at hand. ${ }^{23}$ In addition, decentralizationists postulate that collection development improves when subject specialists do the choosing. Departmental libraries foster a feeling of pride among both faculty and librarians. A centralized library will often overlook problems on which a specialist-oriented library would focus; a decentralized system can arrange hours of service, reference hours, circulation, reserve readings, and all other services to meet the unique needs of the department. By concentrating on service, a departmental library becomes more valuable to the patron than the service provided at a general reference desk. ${ }^{24}$

Branch library proponents dismiss the issue of interrelation of subject areas. They believe that little overlapping of subject materials exists and that only an occasional nondepartmental user would have any need for the departmental library. The final argument for decentralization involves the location of the library within the university community. Proponents of the branch system stipulate that libraries placed close to classrooms better link instruction and research, inspiring scholars and allowing students to identify with their specialities. ${ }^{25}$ At larger schools with graduate and professional departments emphasizing research, branch libraries provide better, more direct service with little increase in cost. ${ }^{26}$ Shoham dismisses the notion that branch libraries increase cost because of duplication of materials and staff. He argues that these costs would be incurred in increased service in the main library. Space would still have to be found and personnel hired to meet the needs of the university. ${ }^{27}$ Shoham also concludes that users prefer accessibility to the greater completeness of the collection.

In summary, the proponents of a decentralized library system consider ease of access and a perception of greater service to the user as the primary reasons for branch libraries. The problems of administration, while recognized, are considered secondary to the basic goal of providing service. Among the major proponents of such a system are faculty members, who view branch libraries as a means of perpetuating their influence in library administration. Because their concern is not library administration, they consider it of lesser importance; use and service are the main goals of the library, in their view. Branch libraries are an entrenched institution on the campuses of large research universities. The possibility of these branch libraries voluntarily giving up their local power is remote.

\section{CENTRALIZATION}

In 1986, Robert A. Seal stated that "for the most part, the history of branch libraries in the twentieth century has been an effort by librarians to centralize facilities and materials." ${ }^{28}$ The early literature notes major problems concerning a decentralized library pattern. In 1929, Mary Venn, a reference librarian at Oberlin College, observed that the interests of departments were so closely allied that duplication was necessary. ${ }^{29}$ Venn felt that centralization is necessary to care for books more economically and efficiently, to provide safety from fire and theft, and to promote interdepartmentalism. ${ }^{30}$ Efficiency through uniform catalog and classification systems outweighs any gain from a decentralized system. Thomas D. Watts of the University of Texas attacked the branch library concept as leading to a "fractionalization" of knowledge. ${ }^{31} \mathrm{He}$ saw 
branch libraries as being inconvenient because users would have to go to many different locations. In addition, particular collections would become isolated from the rest of the library, making them almost inaccessible. Watts also discussed the additional costs in staffing, security, and collection development, and he argued that a decentralized system hinders communications between departments. He concluded that the existence of branch libraries results in loyalty of librarians to a given branch instead of to the university library as a whole. Each department would desire its own branch library, which would destroy the notion of unity of knowledge. ${ }^{32}$

\section{Centralization is necessary to care for books more economically and efficiently, to provide safety from fire and theft, and to promote interdepartmentalism.}

The major advantages of a centralized system are administrative. It is generally agreed that departmental libraries are an administrative nightmare. Problems of control, coordination, and communication are massive..$^{33}$ University librarians have always been opposed to seminar libraries, but did nothing about them until the situation became so critical that it required action. The immediate problem was the cost of duplicating the collection. ${ }^{34}$ Departmental libraries seemed to operate without regard to administrative costs. Centralization of management produces economies of time and money and provides more convenience to the greatest number of users. ${ }^{35}$ Louis Ibbotson recognized the trend toward centralization as early as 1925 , when he stated that greater control was needed to facilitate efficient administration and to avoid duplication. ${ }^{36}$ The early arguments for a centralized system-efficiency, cost, and security-are still central and unassailable. N. Orwin Rush, director of the library at Florida State University, observed in 1962 that if more money were spent on operating departmental librar- ies, less would be available for acquiring more books. ${ }^{37} \mathrm{He}$ found eight important disadvantages of a decentralized system. In his opinion, separate collections waste time, cause administrative problems, duplicate materials, increase costs, result in less effective service, complicate security problems, affect hours of service, and retard interdisciplinary study. ${ }^{38}$ Any advantages gained through departmental libraries, such as greater convenience and access for the researcher, cannot overcome these eight disadvantages, Rush contended. The adverse effects decentralization would have on the general university patron and to interdisciplinary studies far outweigh any possible advantages. ${ }^{39}$

Robert Miller identified seven considerations in the debate regarding centralization, concluding that in at least four of the categories - cost, interrelationship, efficiency, and educational significance - a centralized system was clearly preferable. Cost seems the most obvious factor; a centralized system avoids the problem of duplicating materials, either through multiple purchase or through copying. Also, one main building combines staff, uses staff more efficiently, or reduces staff where necessary. There is no need for a separate catalog, a reserve desk, a reference desk, and other technical services for each branch library. ${ }^{40}$ Overall, a central library provides greater accessibility to the entire collection, not only for users, but for staff, creating better service and a more standardized system. Standard hours of service, circulation regulations, reference services, and interlibrary loan are but a few of the benefits of a centralized system. Also, materials are more secure if they are all in one location. ${ }^{41}$

Two of Miller's considerations-interrelation of subject field and educational significance-are closely akin. He believed that a centralized collection enhances use by patrons in diverse academic fields. While patrons would not walk to a different library to use a departmental collection, they are more apt to do so if it is convenient to the rest of the collection. Miller also stated that a 
centralized library provides a common meeting ground for all students and faculty, helping create a feeling of fellowship and a unity of knowledge, which are cornerstones of a university community. A centralized structure shows that the university administration considers the library a major part of the academic apparatus in which scholars from all disciplines can converge and communicate. As Miller observed, "The day of the narrow man must soon be over.... A central library serves to remind us of the miracle of print and its social importance in higher education." ${ }^{42}$ Miller concluded that centralization is the only choice for a small college-decentralization would only cause headaches. For a large university with an accent on research, decentralization is possible, but only as local conditions warrant and as the budget allows. ${ }^{43}$

\section{DISCUSSION}

The arguments on both sides of the decentralization debate have remained constant throughout this century. The fundamental argument is one of control: Who will control the library-the librarians or the faculty? In many instances, the branch library has become little more than a relic of a system of librarianship that may have had meaning in the academic community of the nineteenth century, but serves little purpose now.

Because they thought departmental libraries would be difficult to abolish, the board of directors of the Association of College and Research Libraries (ACRL) issued eight guidelines in 1975 to be used in determining the need for a branch library:

1. Mission of the parent institution

2. Campus geography

3. Enrollment patterns

4. Space requirements

5. Financial conditions

6. Instructional techniques

7. User expectations and demands

8. External pressures. ${ }^{44}$

The ACRL board believed that an analysis of the need for a branch library should consider the requirements of the branch's primary clientele, as well as the entire academic community. The analysis should compare any possible benefits of a branch library with the current library situation. The comparative analysis must then be viewed in light of the philosophy and mission statement of the library. ${ }^{45}$ Any branch library must fit into the larger framework, objectives, and programs of the university.

The ACRL guidelines included four general principles that should be considered in all cases:

1. Responsibility for the management of all libraries rests with the library administration. Services are best when centralized.

2. The staff of the branches should report to the main library administration (not the departmental faculty).

3. The goals and objectives of the branch should be clear and updated as needed.

4. All branches should have an operating manual that delineates their raison d'etre. ${ }^{46}$

The ACRL directors concluded that a branch library exists solely for the benefit of the users. The quality of the branch depends on its responsiveness to the needs of the community it serves. Once this responsiveness becomes questionable, so does the reason for having a branch library.

Divisional libraries are a possible solution to the controversy. This plan would consolidate departmental libraries into three interdisciplinary libraries: science, humanities, and social science. The consolidation would allow for a degree of interdisciplinary study and would ease the administrative burden of smaller libraries because technical services and administration would remain centralized. As early as 1942, Lawrence Thompson observed that a subject-oriented library system would solve many of the problems of the departmental system. ${ }^{47}$ While this plan encountered much criticism from faculty unwilling to relinquish any influence in the administration of the library, many librarians believe that the divisional plan will eventually replace the departmental system. ${ }^{48}$ 
In 1986, William E. McGrath provided a quantitative study of the centralization debate. He created five distinct disciplinary clusters based on circulation of materials in one discipline by users in another. These clusters included: humanities and arts, social sciences, life sciences, engineering, mathematics and science, and business and quantitative. ${ }^{49}$ McGrath stated, "As a compromise between complete centralization.... and complete decentralization ... it makes sense to consider derived clusters." ${ }^{50}$ The cluster system puts departments into logical groups, and the clusters themselves reflect familiar relationships among departments. McGrath argued that if a central library is outgrowing its main building and some sort of divisional scheme is necessary, this quantitative clustering could provide a guideline for such divisions. He concluded that whether the administrative decision is to centralize or decentralize, the decision can be more realistically supported by an analytical understanding of the collection, its components, and how these components relate to each other. ${ }^{51}$

The literature thoroughly discusses the advantages and disadvantages of decentralization. For the past century, both sides in the debate have presented the same arguments, and some basic axioms have emerged. For instance, rising costs in library service are fundamental in determining if and to what extent decentralization of the library is feasible. In times of plenty, the decentralization argument is ascendent. But with shrinking budgets, the value of cost duplication for the sake of access becomes dubious. Overall, library administration is enhanced with a centralized system. Only in this way can library services be standardized to best serve the entire library community, with special privileges afforded to no specific group.

Clearly, the trend in academic libraries today is towards greater centralization, not only from a cost and administrative view, but from the perspective of a holistic university community. The literature has shown that no one department can provide for the intellectual research needs of a large university. If the library is to emerge as the citadel of knowledge, it must be united to serve the widely divergent components of the academic community. Branch libraries serve only to perpetuate a concept that, while valuable in the nineteenth century to provide needed resources to scholars, has lost much of its reason for being.

\section{Any branch library must fit into the larger framework, objectives, and programs of the university.}

In the age of instant access to a library's holdings through an online catalog, a user's need for physical closeness to the collection is greatly diminished. In fact, Hugh Atkinson stated that "both the administrative attitude and techniques and the technology have changed so radically that the arguments about centralization and decentralization may have been rendered moot by the passage of time." ${ }^{52}$ The new question for librarians is fast becoming not where information is located, but how quickly can the patron receive it. Not only are branches of a single university united by a single online catalog, but nationwide holdings can be tapped through systems like OCLC. According to Anne Woodsworth, "At last the tools seem to be available to dispel the isolation of collections, alleviate inconvenience to users, and provide faster communication among disciplines of knowledge." ${ }^{53}$

The current online catalog unites the various locations and disciplines of a large campus. The recently activated Buffalo Information System Online (BISON) on the campus of the State University of New York-Buffalo is a case in point. SUNY-Buffalo has two campuses approximately five miles apart with numerous branch libraries. Before BISON, the only union catalog was in the main library building. People on one campus could not easily access materials on the other. BISON has changed that. It provides access, with holdings and circulation information, to books, periodicals, 
government documents, microforms, and other library materials in all of the SUNY libraries. BISON will provide dial-up access from users' homes or other locations and access to CD-ROM collections.

The new question for librarians is fast becoming not where information is located, but how quickly can the patron receive it.

The future of library organization is, by necessity, tied to current and future technologies. Irene Hoadley stipulates that "existing facilities need to be reviewed both in terms of current use and of use in a more technological environment." ${ }^{54}$ She believes that consolidation of departmental libraries into larger discipline-oriented libraries would make better use of space, staff, and resources..$^{55}$ Current technology will not end the need for departmental libraries. They will continue to exist because distance and other local conditions warrant it; however, they will no longer be isolated or independent from the larger library system. Experience has shown that modern technology will not remain modern very long. By the year 2000, revolution- ary changes in library organization will be possible. Librarians must be ready to embrace them.

The advocates on both sides of the decentralization argument agree that their main goal is to provide better service to the university community. Local conditions more than anything else will dictate the nature and organizational scheme of the library. The mission of the library, as reflective of the whole university, must be to continue its function as the repository and disseminator of knowledge on a free- and open-access basis. Whichever plan best serves that mission should and must be employed.

More than fifty years ago, Louis Ibbotson summed up this debate:

The measure of the library's success will be gauged by the quality of the books selected; the degree of accessibility offered to the undergraduate, graduate and professor; and the amount of judgment and personality employed in the offering. If there are hindering rules and regulations or physical obstacles, let them be modified; if there are prejudices, may they be overcome; that the university library, whether physically disunited or centralized, may be used and thought of as an intellectual unity. ${ }^{56}$

His words retain their relevance.

\section{REFERENCES AND NOTES}

1. Snunith Shoham, "A Cost-Preference Study of the Decentralization of Academic Library Services," Library Research 4:175 (Summer 1982).

2. Louis T. Ibbotson, "Departmental Libraries," Library Journal 50:853 (Oct. 1925).

3. Ibid.

4. Mary C. Venn, "Departmental Libraries," Libraries 34:193 (May 1929).

5. Ibid.

6. Ibbotson, "Departmental Libraries," p.855.

7. Zella Allen Dixson, "The Departmental Libraries of the University of Chicago," Library Journal 20:376 (Nov. 1895).

8. Ibid.

9. George H. Baker, "Relation of Seminary and Department Libraries to the General University Library," Library Journal 23:104 (Aug. 1898).

10. William Warner Bishop, "The Problem of the Departmental System in University Library," Library Journal 26:17 (Jan. 1901).

11. Ibid.

12. Ibid., p.18.

13. Robert A. Miller, "Centralization Versus Decentralization," American Library Association Bulletin 33:75 (Feb. 1939). 
14. Hugh C. Atkinson, "A Brief for the Other Side," Journal of Academic Librarianship 9:201 (Sept. 1983).

15. Ibid.

16. Ibid.

17. Arthur M. McAnally, "Departments in University Libraries," Library Trends 7:457 (Jan. 1959).

18. Douglas W. Bryant, "Centralization and Decentralization in Academic Libraries: Symposium," College \& Research Libraries 22:333-34 (Sept. 1961).

19. Ibid., p.334.

20. Shoham, "A Cost-Preference Study," p.185.

21. Robert R. Walsh, "Branch Library Planning in Universities," Library Trends 18:210 (Oct. 1969).

22. Ibid., p.211.

23. Miller, "Centralization Versus Decentralization," p.77.

24. Ibid., p.78.

25. Ibid., p.79.

26. Shoham, "A Cost-Preference Study," p.186-87.

27. Ibid., p.187-88.

28. Robert A. Seal, "Academic Branch Libraries," Advances in Librarianship 14:179 (1986).

29. Venn, "Departmental Libraries," p.193.

30. Ibid.

31. Thomas D. Watts, "A Brief for Centralized Library Collections," Journal of Academic Librarianship 9:197 (Sept. 1983).

32. Ibid.

33. J. Michael Bruno, "Decentralization of Academic Libraries," Library Trends 19:313 (Jan. 1971).

34. Lawrence Thompson, "The Historical Background of Departmental and Collegiate Libraries," Library Quarterly 12:61 (Jan. 1942).

35. Bishop, "The Problem of the Departmental System," p.18.

36. Ibbotson, "Departmental Libraries," p.856.

37. N. Orwin Rush, "Central Versus Departmental Libraries," Mountain-Plains Library Quarterly 7:3 (July 1962).

38. Ibid., p.4.

39. Ibid., p.6.

40. Shoham, "A Cost-Preference Study," p.185; and Miller, "Centralization Versus Decentralization," p.76.

41. Ibid., p.185; and p.76-77.

42. Miller, "Centralization Versus Decentralization," p.79.

43. Ibid., p.135.

44. "Guidelines for Branch Libraries in Colleges and Universities," College \& Research Library News 9:281 (Oct. 1975).

45. Ibid., p. $281-82$.

46. Ibid., p.282.

47. Thompson, "The Historical Background," p.50.

48. J. R. Blanchard, "Departmental Libraries in Division Plan University Libraries," College \& Research Libraries 14:247 (July 1953).

49. William E. McGrath, "Circulation Clusters-An Empirical Approach to Decentralization of Academic Libraries," Journal of Academic Librarianship 12:224 (Sept. 1986).

50. Ibid.

51. Ibid., p.226.

52. Atkinson, "A Brief for the Other Side," p.200.

53. Anne Woodsworth, "Decentralization Is the Best Principle of Organization Where It Fits," Journal of Academic Librarianship 9:198 (Sept. 1983).

54. Irene Hoadley, "The World that Awaits Us: Libraries of Tomorrow," Wilson Library Bulletin 61:23 (Oct. 1986).

55. Ibid.

56. Ibbotson, "Departmental Libraries," p.857. 